\title{
Androgen Signaling: Promising Target for Prospective Cancer Therapy
}

\author{
Meenakshi Bandyopadhyay ${ }^{1}$ and Pushpanathan Muthuirulan ${ }^{2^{\star}}$ \\ ${ }^{1}$ Department of Microbiology, Mithibai College, University of Mumbai, Mumbai, India \\ ${ }^{2}$ Laboratory of Gene Regulation and Development, National Institutes of Child Health and Human Development, \\ National Institutes of Health, Bethesda, Maryland, USA
}

\begin{abstract}
Androgen is a steroid hormone that triggers or controls the development and maintenance of male sexual characteristics through their association with nuclear transcription factor known as Androgen Receptor (AR). AR signaling cascade mechanism plays a critical role in the growth and development of male and female reproductive organs, but the latter to a lesser extent. During recent years, abnormal amplification of androgen gene and dysfunction of AR gene expression have been shown to be associated with wide range of malignancies in humans including prostate cancer, bladder cancer, esophageal cancer, neuroblastomas and also certain types of breast cancers in females. Therapies including administration of antiandrogens, deprivation or ablation of androgens, use of androgen receptor antagonist and androgen synthesis inhibitors have been successfully implemented in the treatment of androgen-dependent conditions in both males and females. However, the treatment failure associated with these therapies due to robust acquired resistance development by malignant cells has led to increased mortality, especially in Castration-Resistant Prostate Cancer (CRPC) patients. This mini review article summarizes different androgen related pathologies and list molecules that have been proved to be effective in treating androgen associated malignancies. Further, this article also identifies the benefits and discusses the challenges and opportunities of discovering new drugs targeting androgen and AR regulated mechanisms in cancers therapeutics.
\end{abstract}

Keywords

Steroid hormone, Androgen, Androgen receptor, Antiandrogen, Antagonist, Cancer therapy

\section{Introduction}

Androgens are a class of steroid hormones in humans controlling the development and maintenance of male sexual characteristics [1]. Testosterone and Dihydrotestosterone (DHT) are the most common androgens found in vertebrates that plays an equivalent role in male sexual development. In general, testosterone is converted to DHT and $17 \beta$-estradiol (E2), the main active estrogen by $5 \alpha$-reductase type- $1 / 2$, 3-oxo- $5 \alpha$-steroid 4 -dehydrogenase- 1/2 (SRD5A1/2) and aromatase [2]. Other androgens in vertebrates include Dehydroepiandrosterone (DHEA), Androstenedione (A4) and Androstenediol (A5). Androgens mainly regulate the growth and sexual characteristics by binding to nuclear receptor super family transcription factor known as Androgen Receptors (AR). AR signaling is highly important in vertebrates for prostate, sexual and physiological development [3]. Androgen stimulates growth of reproductive tract and induces differentiation of epididymis, seminal vesicles, and vas deferens. At the onset of male pubertal changes, androgens play important role in enlargement of larynx and thickening of vocal cords that deepens male voice. Androgens possess anabolic effects on bone tissues and skeletal muscles. They modulate distribution of subcutaneous fat and play critical role in libido development [2]. Androgens have also been shown to modulate the activity and/or expression of drug detoxifying enzymes

*Corresponding author: Pushpanathan Muthuirulan, Laboratory of Gene Regulation and Development, National Institutes of Child Health and Human Development, National Institutes of Health, Bethesda, Maryland 20892, USA, Tel: +1301-674-3108, E-mail: pushpanathan31@gmail.com

Received: July 03, 2017; Accepted: November 04, 2017; Published online: November 06, 2017

Citation: Bandyopadhyay M, Muthuirulan P (2017) Androgen Signaling: Promising Target for Prospective Cancer Therapy. J Drug Des Devel 1(1):1-10

Copyright: (C 2017 Bandyopadhyay M, et al. This is an open-access article distributed under the terms of the Creative Commons Attribution License, which permits unrestricted use, distribution, and reproduction in any medium, provided the original author and source are credited. 
such as cytochrome P450 (e.g., cytochrome P450, family 4, subfamily B, polypeptide 1 ) and Uridine 5 '-diphospho-glucuronosyltransferase (e.g., UDP Glucuronosyl transferase Family 1 Member A subtype) through AR signaling pathways [1].

Androgen Receptor (AR) is a member of steroid and nuclear receptor super family expressed at very low levels in many human tissues [4]. The AR has a molecular weight of $110 \mathrm{Kd}$, which composed of 919 amino acids. The gene encoding AR in human is located on the $\mathrm{X}$-chromosome (Xq11-12) and it is formed of 8 exons and 7 introns [5]. AR is a transcription factor that can be activated by binding of specific ligands such as testosterone and 5-dihydrotestosterone. AR protein has 3 domains: (a) Ligand-Binding Domain (LBD) that binds to androgens and antiandrogens, (b) DNA-Binding Domain (DBD) that binds to Androgen Response Elements (AREs) present in the enhancers and promoters of target genes and, (c) N-Terminal Domain (NTD) that contains Activation Function-1 (AF-1), which is responsible for most of the AR's transcriptional activity. The NTD is an unfolded domain, which is highly disordered. Therefore, targeting NTD domain for drug development is extremely difficult. AF-1 comprises of two transcriptional activation units: Tau1 and Tau5, which are essential for transcriptional activation of both Full-Length AR (FL-AR) and constitutively active AR splice variants lacking the LBD. The hinge region of AR contains a Nuclear Translocation Sequence (NTS) that import AR into cell nucleus by nuclear transport $[4,6]$. In the absence of androgen, inactive AR is localized in the cytoplasm where it forms an association with a Heat Shock Protein (HSP) 90 chaperone complex that undergoes proteasome-mediated degradation [2]. However, in the presence of androgen, AR becomes hyperphosphorylated, then translocated to the nucleus and undergoes dimerization. After dimerization, AR interacts with other co-regulatory proteins and transcriptional machinery on AREs of target genes to initiate transcription [4]. AR has also been known to induce apoptosis at certain conditions. Several regulators such as Breast Cancer Genes 1 (BRCA1), Smad3 and serine-threonine kinase Akt (protein kinase B) regulate androgen-mediated apoptosis. The abnormal amplification of androgen gene and dysregulation of AR gene expression have resulted in wide range of malignancies in humans. Thus, targeting androgen and AR signaling cascade would open up new doors to treat androgen dependent malignancies in humans.

\section{Role of Androgen in Different Cancer Types}

An abnormal expression of androgen and AR have been implicated in wide range of pathologies including prostate cancer, breast cancer, esophageal cancer, neuroblastomas, bladder cancer and salivary gland cancer (Figure 1).

\section{Prostate cancer}

The prostate requires optimal levels of steroid androgens and AR for maintenance of its architecture and function [7]. Testosterone and DHT plays major role in the activation of growth factors by influencing cell signaling through AR. Normal prostate can be transformed into benign prostrate hyperplasia or prostatic cancer under very high levels of androgen $[8,9]$. It has been reported earlier that prostate cancer occurs rarely in eunuchs or in men deficient in $5 a$-reductases, a key enzyme that

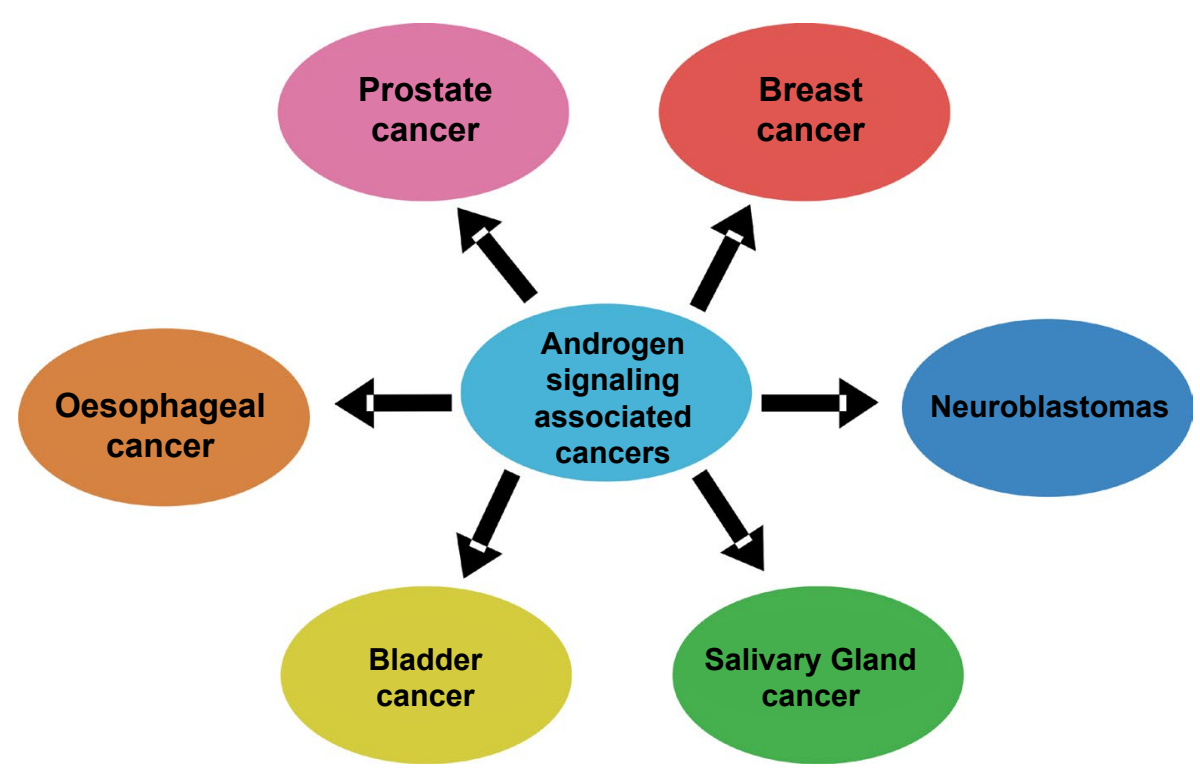

Figure 1: Androgen signaling associated pathologies in humans. An abnormal expression of androgen and AR have been associated in wide range of cancers in human including prostate cancer, breast cancer, oesophageal cancer, neuroblastomas, bladder cancer and salivary gland cancer. 
converts testosterone to $5 a$-dihydrotestosterone [10]. The Prostate-Specific Membrane Antigen (PSMA) is expressed in $90 \%$ of prostate carcinomas. PSMA is a type II transmembrane protein with glutamate-carboxypeptidase activity, which showed several biological features with target structure more appropriate for ligand development for nuclear medicine. It serves as an excellent target for diagnosis and therapy owing to its high specificity at an undifferentiated stage. AR regulates Prostate-Specific Antigen (PSA) expression in prostate cancer cells. Earlier studies have also shown that the suppression of AR signaling pathways induced apoptosis in prostate cancer [3]. Androgens help in survival and proliferation of both benign and malignant prostate epithelial cells. Thus, the patients are routinely treated using Androgen Deprivation Therapy (ADT), either via orchiectomy (surgical castration) or Luteinizing Hormone-Releasing Hormone (LHRH) agonist/antagonist (chemical castration) to reduce the levels of androgen in blood [11]. ADT reduces serum testosterone to castrate levels with a testosterone concentration of $<20 \mathrm{ng} / \mathrm{dl}$. Surgical castration has shown to drop the testosterone levels upto $15 \mathrm{ng} / \mathrm{dl}$. Despite ADT, prostate cancer cells survive and grow through androgen independent mechanisms [12]. In prostate cancer, AR gets accumulated within nucleus in the presence of androgens [13]. ADT alone or in combination with docetaxel chemotherapy is initially effective in majority of the patients, but in some, the disease progresses to an incurable stage called Castration-Resistant Prostate Cancer (CRPC) [11].

\section{Castration Resistant Prostate Cancer (CRPC)}

Most patients with persistent AR signaling eventually progress to fatal condition known as Castration-Resistant Prostate Cancer (CRPC) [14]. AR contributes to resistance mechanisms in CRPC patients through AR amplification (increase in androgen sensitivity and antagonist-agonist conversion), AR mutations (gain of function mutations, recurrent point mutations in the LBD like L702H, W742C, H875Y, T878A and AR promiscuity), AR Variants (ARVs) (LBD deficient, ARV7 types resistant to abiaterone or enzalutamide and ARVs independent of androgens), AR activation by growth factors [i.e., Insulin-like Growth Factor-1 (IGF-1), Keratinocyte Growth Factor (KGF) and Epidermal Growth Factor (EGF)], receptor tyrosine kinase-activated pathway, AKT pathway, Prostate Cancer Non-Coding RNA1 (PCNCR1) dependent mechanisms, ligand-independent activation of AR by cAMP-dependent protein kinase and IL-6 pathways, increased expression of AR coactivators and intratumoral de novo synthesis of androgens [12,15].

CRPC patients showed a continuous increase in serum PSA levels despite castrate levels of testosterone. CRPC remains incurable with survival of patients for 2 to 3 year. CRPC patients have genetic aberrations that resides with AR (63\%), tumor protein p53 (54\%), ETS family (57\%) and Phosphatase and Tensin Homolog (PTEN) (41\%). In CRPC patients, androgens levels within the prostate remain high and support tumor growth survival via androgen-regulated genes. In CRPC cells, DHT is produced either by the classical pathway (or) backdoor pathway (or) 5a-dione pathway. There is also a feedback loop that exists between miRNAs and AR signaling. It has been shown in tumors and serum of CRPC patients that androgens induce miR-21 expression through $A R$ complex and positive feedback loop through PTEN [11]. Increase in Aldo-Keto Reductase family 1 member C3 (AKR1C3), 17 $\beta$-Hydroxysteroid Dehydrogenase type 3 (17ßHSD3) levels and decrease in Steroid 5 Alpha-Reductase 2 (SRD5A2) levels have been demonstrated in clinical and metastatic CRPC samples. Metastatic Castrate Resistant Prostate Cancer (mCRPC) has been shown with notable increase in the levels of Fatty Acid Synthase (FASN), Cytochrome P450 17A1 (CYP17A1), $3 \beta H S D 1$, and $3 \beta H S D 2$ genes in comparison with primary prostate cancer [16].

DHT synthesis has been shown to be associated with increased levels of hydroxy-delta-5-steroid dehydrogenase, 3-beta- and steroid delta-isomerase 1/2 (HSD3B1/2), 3-oxo-5a-steroid 4-dehydrogenase 1 (SRD5A1) and AKR1C3. HSD3B1 and HSD3B2 encode for two isoenzymes responsible for the conversion of DHEA to $\mathrm{AD}$. Aromatase is highly overexpressed in CRPC that converts $\mathrm{AD}$ and testosterone to estrogens suggesting its role in resistance mechanisms [17]. The aldo-keto reductase has been shown to be involved in intratumoral steroidogenesis [16]. Humans contain four AKR1C isoforms that reduces $5 a$-DHT to $3 \alpha$-diol. AKR1C1 is a 20-ketosteroid reductase that forms $20 \alpha$-hydroxyprogesterone and inactivates progesterone. AKR1C2 is a 3 -ketosteroid reductase that solely reduces and converts $5 a$-DHT to $3 a$-diol. AKR1C3 is a 17 -ketosteroid reductase that converts $\Delta 4$-androstene-3,17-dione to testosterone and estrone to $17 \beta$-estradiol. AKR1C4 is a liver specific 3-ketosteroid reductase [18]. Human Aldo-Keto Reductase family 1 member C3 (AKR1C3) was initially identified as an enzyme in reducing $5 \alpha$-dihydrotestosterone $(5 \alpha-\mathrm{DHT})$ to $5 \alpha$-androstane- $3 \alpha, 17 \beta$-diol ( $3 \alpha$-diol) and oxidizing $3 \alpha$-diol to androsterone. AKR1C3 has been found in testis and prostate [17].

\section{Breast cancer}

Estrogen and its Receptor (ER) have been known to play a pivotal role in breast cancers. ERa-positive diseases accounts for majority of breast cancers. The adjuvant therapy for breast cancer includes, use of antiestrogen (tamoxifen) or aromatase inhibitors. During recent years, Androgen and its Receptor (AR) have been report- 
ed to be involved in breast cancer [19]. Androgen can influence breast cancer cell growth by aromatization of estrogens. There is a significant correlation existing between the blood androgen levels and breast cancer risk in premenopausal and postmenopausal women [20]. AR was found to be co-localized with ERa in breast cancer tissues that depicted the nuclear interaction of AR in ERa signaling. However, different subtypes of breast cancer have androgen receptor signaling without the co-operation of estrogen receptors. Thus, the clinical role of AR in primary breast cancer varies in different subtypes of breast cancers. In ERa negative cancers, Human Epidermal Growth Factor Receptor 2 (HER2) expressions has been found along with high expression levels of AR [21]. Triple Negative Breast Cancer (TNBC) is another type of breast cancer negative for ERa, Progesterone Receptor (PR) and HER2. At some exceptional cases, TNBC was found to be positive for AR. AR-positive breast cancer is more likely to be associated with Phosphatidylinositol-4,5-bisphosphate 3-Kinase, Catalytic subunit Alpha (PIK3CA) mutation, but has no association with P53 mutation. Previous reports have shown that AR-positive TNBC is more likely to have activation of Epidermal Growth Factor Receptor (EGFR) and Platelet-Derived Growth Factor Receptor (PDGFR $\beta$ ), and enriched for PI3KCA mutations [22]. The studies using DHEA androgen have given a very different perspective on its role in breast cancer. DHEA has been shown to decrease the secretion of IL-12 p70, sIL-2ra, IL-1a, IL-6 and IL-8 in cell lines MDA-MB-231, MCF-7 and ZR-75-30. IL-1ra and IL-1b were diminished in MDA-MB-231 and ZR75-30 cells exposed to DHEA, while IL-2 decreased in MCF-7 and MDAMB-231 cells. Interestingly, DHEA has also been shown to greatly reduce the secretion of Vascular Endothelial Growth Factor (VEGF) in MCF-7 cells. DHEA has also been shown to decrease the migration and invasion of MCF-7 [23].

\section{Esophageal cancer}

Gastrointestinal tissues are not usually considered to be targets for steroid hormones. However, the function of AR in these tissues is largely unknown. Certain studies have reported AR expression in patients with colon adenocarcinoma. In Esophageal Squamous Cell Carcinoma (ESCC), AR expression did not correlate with patient age or tumor location, but rather it correlates well with other factors like gender, tumor differentiation, invasion and status of lymph node metastasis. Mutations have profound effect on AR signaling mechanisms. A short (GGC) $\mathrm{n}$ allele mutation found in South African men showed increased AR activity, which would best explain the risk of Oesophageal cancer in men with this mutation. Some patients with Esophageal Adeno Carcinoma (EAC) have shown positive results for AR upon staining the cell stroma. This level has been decreased after surgical removal of cancer indicating the involvement of androgen in the pathogenesis and progression of diseases [24].

\section{Neuroblastomas}

Neuroblastoma (NB) is the most common extracranial solid tumor causing $15 \%$ of fatalities in children. Primary site of NB is retroperitoneum. The patients with neuroblastoma generally show aggressive local growth and metastasize of tumor to regional lymph nodes, liver, bone marrow, and bone cortex. The incidence of NB has been shown to be slightly higher in males than females. Despite major advances in therapies, neuroblastoma is still associated with a high morbidity and mortality. During recent years, androgen (R1881) has been reported to increase the proliferation and migration of neuroblastoma cells. However, the molecular pathogenesis underlying NB is not extensively studied. Previous studies have shown that use of androgen receptor antagonists such as enzalutamide (MDV3100) and Apalutamide (ARN509) decreased the proliferation of neuroblastoma cells suggesting the role of androgen and AR in neuroblastoma formation and disease progression [25].

\section{Bladder cancer}

Male internal genitalia (prostate, bulbourethral gland and urothelium) are generally derived from the urogenital sinus endoderm. AR has been shown to present in urothelium and bladder submucosa, where it regulates urine storage and urinary tract functions. AR signaling plays major role in high-grade prostatic intraepithelial neoplasia and prostatic adenocarcinoma. In addition, abundant expression of GATA Binding Protein 3 (GATA3), a zinc-finger transcription factor in urothelial cells also contribute to urothelial cancer along with AR. Loss of GATA3 expression in a subset of bladder cancers occur due to AR over expression or androgen treatment. Thus, androgens have been shown to induce growth of AR-positive bladder cancer cells [1]. Previous studies have shown that AR knockdown inhibited cell proliferation of bladder cancer lines grown in presence of androgens. Androgen-mediated AR signaling induced epithelial-to-mesenchymal transition. They also modulate the expression of Slug and activity of $\beta$-catenin/Wnt signaling in bladder cancer cells. Earlier reports have shown that AR and $\beta$-catenin co-expressed at the nuclei of bladder cancer cells and forms a complex with T-cell factor in the presence of androgens. Further, AR expression in bladder tumors was also found to be enhanced by co-activators like Nuclear Receptor Co-Activator 1, 2 \& 3 (NCOA1, 2 and 3), CREB-binding protein, and E1 A-associated Protein p300 (EP300). Interestingly, expression of JmjC Domain-Containing Histone Demethylation 


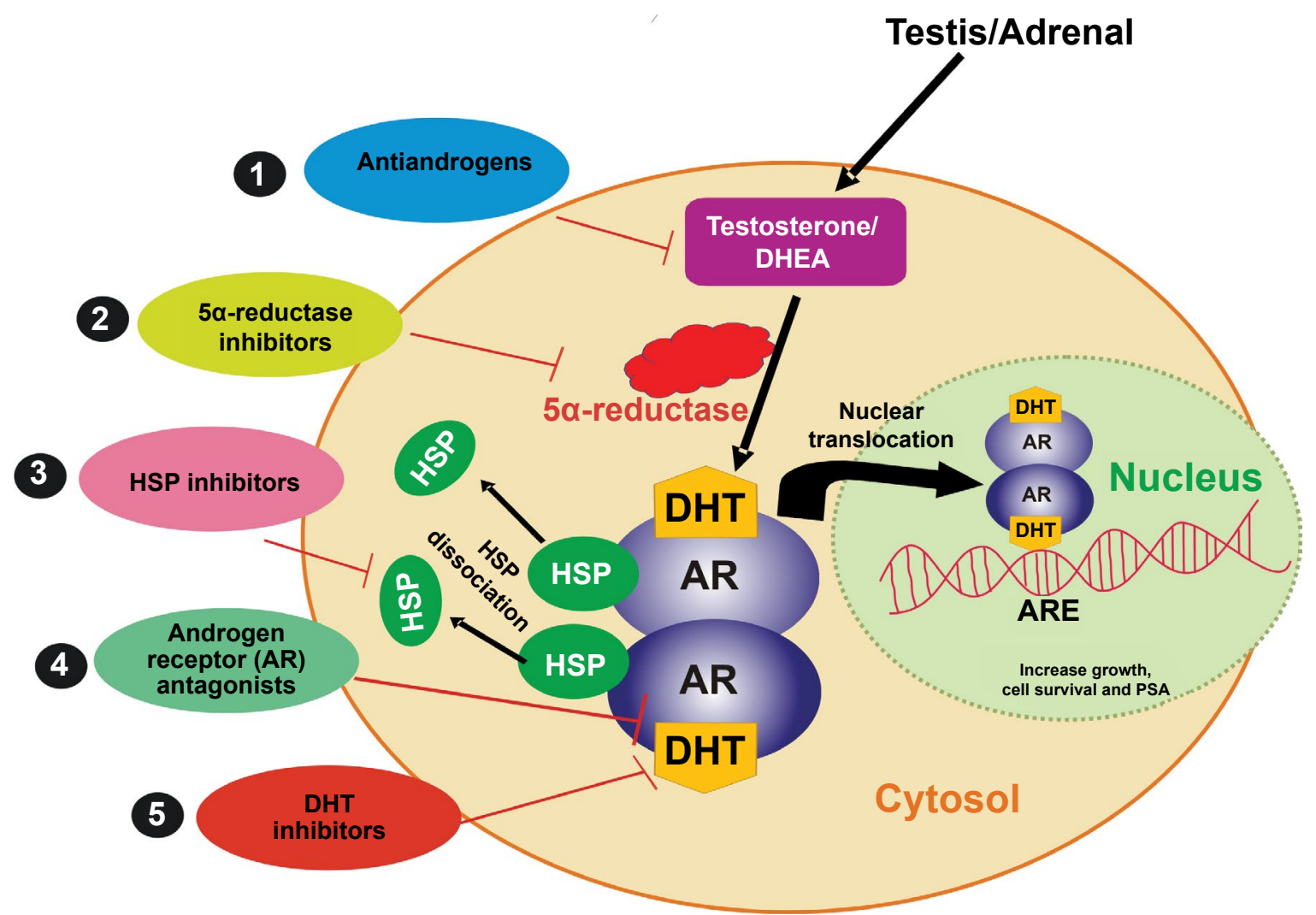

Figure 2: Androgen signaling targets for prospective cancer therapy. Androgen (testosterone and DHEA) and Androgen Receptors $(A R)$ in cells regulates the activity of several cancer-related genes. AR signaling is the primary mechanism by which most cancer cells grow and spread, where testosterone or DHEA gets converted into DHT by $5 a$-reductase enzyme. DHT then forms complex with AR by dissociating HSP90 and the complex gets translocated into nucleus to activate cell survival and cancer related genes. Targeting androgen signaling pathways in cancer cells using antiandrogens, 5a-reductase inhibitor, HSP90 inhibitors, androgen receptors agonist and DHT inhibitors would possibly control androgen associated malignancies in human.

Protein 3A (JMJD2A) and Lysine (K)-Specific Demethylase 1A (LSD1) also know to mediate AR transactivation via histone-lysine demethylation mechanisms [1].

\section{Salivary gland cancer}

Salivary Gland Cancer (SGC) is a malignant condition that forms in the tissues of salivary glands. There are different types of SGC including Salivary Duct Carcinoma (SDC), Adenoid Cystic Carcinoma (ACC), Muco Epidermoid Carcinoma (MEC), secretory carcinoma and Polymorphous Low Grade Adenocarcinoma (PLGA). Based on Immunohistochemistry (IHC) and RNA sequencing, SGS have been classified into AR IHC-positive and AR IHC-negative. AR IHC-negative SDCs are known to possess low levels of AR mRNA. In a few cases, AR IHC-negative and AR IHC-positive shared similar patterns of AR signaling with AR positive breast cancers. Adenocarcinoma (AC NOS) and Acinic Cell Carcinoma (AcCC) are AR-positive SDCs. It is interesting to note that only a small subset of MEC and ACC have detectable levels of AR expression, whereas PLGA and Basal Cell Adenocarcinoma (BCAC) showed rare expression of AR [26].

\section{Drug Targets for Cancer Therapeutics}

Targeting androgen and AR related mechanisms remains as the gold standard treatment for many different types of cancers (Figure 2). Antiandrogens are androgen antagonist that prevents activation of AR and cause tumor regression by competing androgen binding with AR Ligand Binding Domain (LBD) [4,26,27]. Bicalutamide, nilutamide, flutamide and enzalutamide are some of antiandrogen drugs used in tumor regression. Bicalutamide, nilutamide and flutamide are first-generation, whereas, enzalutamide is second generation antiandrogens [28]. Other AR targeted therapies include androgen ablation or androgen deprivation therapy, which suppress or block the production of male androgens. This can be achieved by orchiectomy or Luteinizing Hormone-Releasing Hormone (LHRH) agonists/ antagonists, 17-ketosteroid reductase inhibitors or by down regulating the Gonadotropin-Releasing Hormone (GnRH) receptor signaling [29]. Triptorelin and goserelin are GnRH agonists, which down regulate the production of Luteinizing Hormone (LH) and reduced serum testosterone levels [26]. Abiraterone is a CYP17A1 inhibitor that blocks the conversion of pregnenolone to 
DHT. Abiraterone Acetate (AA) is a selective inhibitor of both 17a-hydroxylase and c17, 20-lyase. It mainly targets adrenal and tumor intracrine androgen biosynthesis [28]. In many cancers, the conversion of inactive steroid hormone precursors to E2 is accomplished from sulfated estrogens (inactive) in the sulfatase pathways. Steroid Sulfatase (STS) enzymes in sulfatase pathway activate estrogen and estrogen sulfotransferase, which converts active Estrone (E1) and other estrogens to their inactive sulfates. Increased expression of STS in malignant tumor cells has been associated with increased levels of active estrogens that stimulate cell proliferation and cancer progression [30]. Therefore, targeting sulfatase pathways with STS inhibitors would also offer additional benefits in the cancer therapy. STS inhibitors combined with other androgen signaling inhibitors can effectively prevent cancer cell proliferation and progression.

\section{Drug Resistance and Prospective Drug Devel- opment}

In many tissues including the prostate, dihydrotestosterone or 5a-dihydrotestosterone acts as the most active androgen. Therefore, targeting $5 \alpha$-reductase enzyme that catalyzes the reductive conversion of testosterone to $5 a$-dihydrotestosterone would be the promising therapeutic target to treat androgen-dependent diseases in humans [31]. The mechanism of AR dependent resistance development in cancer cells include up regulation of AR, formation of AR splice variants, AR mutations and up regulation of Glucocorticoid Receptor (GR). GR up regulation in cancer cells is a potential resistance mechanism against the drug, enzalutamide [28]. Point mutations in $\mathrm{AR}$ are another mechanism of acquired resistance to abi- raterone and next-generation AR antagonists (enzalutamide and apalutamide). The frequency of AR mutations in normal cells is lower; however, the frequency has been known to increase during advanced stages of disease due to therapy based selection of aberrant receptors. For instance, treatment with drugs such as bicalutamide and flutamide droves the selection of ARW741L/C and ARH874Y/ART877A mutations in tumor cell growth [27]. AR-independent mechanisms include PI3K/AKT pathway activation (often resulting from loss of phosphatase and tensin homolog), tumor protein p53 mutations, Retinoblastoma (RB) protein loss, expression of Aurora Kinase A (AURKA) and proto-oncogene protein (N-Myc) alteration in DNA-repair genes [32]. Other pathways such as Phosphatidylinositol 3-Kinase (PI3K)/Protein Kinase B (PKB, also known as AKT), Ras/Mitogen-Activated Protein Kinases (MAPK), and Protein Kinase A (PKA) also contributed for cancer cell resistance to chemotherapy [33]. Previous studies have shown that androgens in prostate cancer cells have suppressed the expression of Protein Kinase D1 (PKD1) through fibroblast growth factor receptor substrate 2. Thus, PKD1 was identified as a novel androgen-suppressed gene, which could be potentially down regulated by androgen through a novel AR/FRS2/MEK/ ERK pathway. Up-regulation of PKD1 by anti-androgens may also contribute to resistance development in prostate cancer cells $[34,35]$. Targeting PKD1 would be the other possible ways to treat prostate cancer. Thus, the treatment failures associated with current therapies warrants more intensive research to be conducted toward discovering novel therapeutic agents against androgens and AR related signaling mechanism. The molecules targeting androgen and $\mathrm{AR}$ related mechanisms are listed in Table 1.

Table 1: List of bioactive molecules/compounds targeting androgen and AR related mechanisms.

\begin{tabular}{|c|c|c|c|c|}
\hline Molecule/compound & $\begin{array}{l}\text { Nature of the } \\
\text { molecule/compound }\end{array}$ & Targets & Mode of action & References \\
\hline Niphatenone B & $\begin{array}{l}\text { Glycerol ether initially } \\
\text { isolated from the } \\
\text { marine sponge Niphates } \\
\text { digitalis }\end{array}$ & $\begin{array}{l}\text { Androgen } \\
\text { Receptor } \\
\text { N-Terminal } \\
\text { Domain }\end{array}$ & $\begin{array}{l}\text { Inhibits transactivation of AR NTD, } \\
\text { blocks endogenous expression of AR- } \\
\text { regulated genes PSA and Kallikrein-2, } \\
\text { covalent binding to AR AF-1 peptide. }\end{array}$ & Banuelos, et al. [4] \\
\hline Sintokamide A & $\begin{array}{l}\text { Natural compound } \\
\text { isolated and } \\
\text { purified from the marine } \\
\text { sponge Dysidea sp. }\end{array}$ & $\begin{array}{l}\text { AF-1 of } \\
\text { Androgen } \\
\text { receptor }\end{array}$ & $\begin{array}{l}\text { Inhibits transactivation of AR NTD, } \\
\text { attenuate transcriptional activities of } \\
\text { both full-length AR and constitutively } \\
\text { active AR splice variants AR-V567es, } \\
\text { repressed androgen-induced levels } \\
\text { of transcripts of FL-AR-regulated } \\
\text { genes (KLK3/PSA, KLK2, TMPRSS2, } \\
\text { NKX3.1, FKBP5, and SLC1A1). }\end{array}$ & Banuelos, et al. [6] \\
\hline Isosilybin A & $\begin{array}{l}\text { Flavolignan; one of } \\
\text { the } 7 \text { components of } \\
\text { Silymarin }\end{array}$ & $\begin{array}{l}\text { Androgen } \\
\text { receptor } \\
\text { signaling }\end{array}$ & $\begin{array}{l}\text { Decreases AR and PSA level in } \\
\text { prostate cancer cells. }\end{array}$ & Deep, et al. [36] \\
\hline $\begin{array}{l}\text { Thiostrepton and } \\
\text { Siomycin A }\end{array}$ & Thiazole antibiotics & $\begin{array}{l}\text { AR signaling in } \\
\text { neurons }\end{array}$ & $\begin{array}{l}\text { Reduces expression of FOXM1 } \\
\text { transcription factor and ß-catenin, } \\
\text { both required for localization and } \\
\text { expression of AR. }\end{array}$ & $\begin{array}{l}\text { Otto-Duessel, et al. } \\
\text { [37] }\end{array}$ \\
\hline
\end{tabular}


Citation: Bandyopadhyay M, Muthuirulan P (2017) Androgen Signaling: Promising Target for Prospective Cancer Therapy. J Drug Des Devel 1(1):1-10

\begin{tabular}{|c|c|c|c|c|}
\hline Emodin & $\begin{array}{l}\text { Anthraquinone } \\
\text { compound obtained } \\
\text { from } 50 \% \text { ethanolic } \\
\text { extract of Polygonum } \\
\text { multiflorum Thunb. } \\
\text { (Family: Polygonaceae) }\end{array}$ & 5a-reductase & Inhibits $5 \alpha-$-reductase enzyme activity. & Cho, et al. [31] \\
\hline $\begin{array}{l}\text { 6-(3,4-dihydro-1H- } \\
\text { isoquinolin-2-yl)-N- } \\
\text { (6-methylpyridin-2-yl) } \\
\text { nicotinamide-26 } \\
\text { (DIMN-26) }\end{array}$ & $\begin{array}{l}\text { 6-(3,4-Dihydro-1H- } \\
\text { isoquinoline-2-yl)-N-(6- } \\
\text { methoxypyridine-2-yl) } \\
\text { nicotinamide-26 }\end{array}$ & AR signaling & $\begin{array}{l}\text { Inhibits Dihydrotestosterone (DHT) } \\
\text { production, induce cell growth and } \\
\text { proliferation, suppresses DHT-induced } \\
\text { transcriptional activity and nuclear } \\
\text { translocation of AR, binds to LBD } \\
\text { (Ligand Binding Domain) of AR, reduced } \\
\text { mRNA levels of PSA, AR, Ste20-related } \\
\text { Protein Proline/Alanine-Rich Kinase } \\
\text { (SPAK), Beta-2-Microglobulin (B2M), } \\
\text { and Selenoprotein P1(SEPP1). }\end{array}$ & Choi, et al. [33] \\
\hline $\begin{array}{l}\text { Tocopheryl } \\
\text { Quinone (TQ) }\end{array}$ & $\begin{array}{l}\text { Oxidation product of } \\
\text { alpha-tocopherol }\end{array}$ & $\begin{array}{l}\text { Androgen } \\
\text { receptor in } \\
\text { prostate cancer } \\
\text { cells }\end{array}$ & $\begin{array}{l}\text { Decreases gene expression of } \\
\text { TM4SF1, KLK2, FOXA1 and PSA. }\end{array}$ & Fajardo, et al. [38] \\
\hline $\begin{array}{l}\text { 1,4-Substituted } \\
\text { Triazoles }\end{array}$ & $\begin{array}{l}\text { Non-steroidal } \\
\text { antiandrogen }\end{array}$ & $\begin{array}{l}\text { Androgen } \\
\text { receptor in } \\
\text { prostate cancer } \\
\text { cells }\end{array}$ & Reduces the level of PSA. & Ferroni, et al. [39] \\
\hline $\begin{array}{l}\text { Darolutamide } \\
\text { (ODM-20) }\end{array}$ & $\begin{array}{l}\text { Non-steroidal } \\
\text { antiandrogen }\end{array}$ & $\begin{array}{l}\text { Androgen } \\
\text { receptor of } \\
\text { CRPC cells }\end{array}$ & $\begin{array}{l}\text { Reduces serum PSA in CRPC and } \\
\text { blocks nuclear translocation of AR. }\end{array}$ & Fizazi, et al. [40] \\
\hline Zyflamend & $\begin{array}{l}\text { Polyherbal preparation } \\
\text { consisting of the } \\
\text { supercritical } \mathrm{CO}_{2} \text { fluid } \\
\text { extracts of } 10 \text { different } \\
\text { herbs }\end{array}$ & $\begin{array}{l}\text { Androgen } \\
\text { receptor in } \\
\text { CRPC model }\end{array}$ & Reduces mRNA levels of AR and PSA. & Huang, et al. [41] \\
\hline M-Mel & $\begin{array}{l}\text { (1- (pyridine-2-yl)-3-(m- } \\
\text { tolyl) imidazo [1,5-a] } \\
\text { pyridine), a derivative } \\
\text { of HIMP (3-phenyl- } \\
\text { 1-(pyridine-2-yl) } \\
\text { imidazo[1,5-a]pyridine) }\end{array}$ & $\begin{array}{l}\text { Androgen } \\
\text { receptor of } \\
\text { CRPC }\end{array}$ & $\begin{array}{l}\text { Methyl group on the para position of } \\
\text { the benzene ring in M-Mel suppress } \\
\text { AR activity, decreases levels of PSA } \\
\text { and p66Shc (a protein regulated by } \\
\text { androgens). }\end{array}$ & Ingersoll, et al. [42] \\
\hline Minnelide & $\begin{array}{l}\text { Water soluble pro-drug } \\
\text { of triptolide, a diterpene } \\
\text { triepoxide isolated } \\
\text { from a Chinese herb, } \\
\text { Tripterygium wilfordii }\end{array}$ & $\begin{array}{l}\text { Androgen } \\
\text { receptor and its } \\
\text { splice variants of } \\
\text { CRPC }\end{array}$ & $\begin{array}{l}\text { Induces apoptosis in androgen } \\
\text { dependent and CRPC cells, inhibits } \\
\text { AR transcription and downstream AR } \\
\text { targets such as PSA and NKX3.1, } \\
\text { prevents translocation of Sp1 to the } \\
\text { nucleus (a transcription factor of AR). }\end{array}$ & Isharwal, et al. [43] \\
\hline Decursin & $\begin{array}{l}\text { Ethanol extract of herbal } \\
\text { formula containing } \\
\text { Korean Angelica Gigas } \\
\text { Nakai (AGN) root and } 9 \\
\text { Oriental herbs }\end{array}$ & $\begin{array}{l}\text { Antiandrogen } \\
\text { and androgen } \\
\text { receptor }\end{array}$ & $\begin{array}{l}\text { Suppression of PSA mRNA and } \\
\text { protein, inhibits androgen-stimulated } \\
\text { AR translocation to the nucleus, } \\
\text { down-regulates AR protein abundance } \\
\text { without interfering AR transcription. }\end{array}$ & Jiang, et al. [10] \\
\hline $\begin{array}{l}\text { Cyclopropane } \\
(1 \mathrm{~S}, 2 \mathrm{R})-27\end{array}$ & Thioether isostere & $\begin{array}{l}\text { Nuclear } \\
\text { androgen } \\
\text { receptor }\end{array}$ & Reduction in PSA activity. & Johnson, et al. [14] \\
\hline Lambertianic acid & $\begin{array}{l}\text { Isolated Pinus } \\
\text { koraiensis Siebold and } \\
\text { Zucc (Family: Pinaceae) }\end{array}$ & $\begin{array}{l}\text { Androgen } \\
\text { receptor }\end{array}$ & Attenuates expression of AR and PSA. & Lee, et al. [3] \\
\hline D4A & $\begin{array}{l}\text { A converted form of } \\
\text { abiraterone }\end{array}$ & $\begin{array}{l}\text { Androgen } \\
\text { receptor }\end{array}$ & $\begin{array}{l}\text { Inhibits CYP17A1, 3ßHSD and } \\
\text { SRD5A, required for DHT synthesis, } \\
\text { AR antagonist, Inhibits DHT-induced } \\
\text { AR chromatin occupancy on the PSA, } \\
\text { TMPRSS2 and FKBP5 regulatory } \\
\text { elements on chromatin. }\end{array}$ & Li, et al. [1] \\
\hline
\end{tabular}


Citation: Bandyopadhyay M, Muthuirulan P (2017) Androgen Signaling: Promising Target for Prospective Cancer Therapy. J Drug Des Devel 1(1):1-10

\begin{tabular}{|c|c|c|c|c|}
\hline $\begin{array}{l}\text { Cryptotan } \\
\text { shinone }\end{array}$ & $\begin{array}{l}\text { Active extract of Salvia } \\
\text { miltiorrhiza Bunge } \\
\text { (Danshen), chemical } \\
\text { name: (R)-1,2,6,7,8,9- } \\
\text { Hexahydro-1,6,6- } \\
\text { trimethyl- phenanthro } \\
(1,2-b) \text { furan-10,11- } \\
\text { dione }\end{array}$ & $\begin{array}{l}\text { Androgen } \\
\text { receptor in } \\
\text { prostate cancer }\end{array}$ & $\begin{array}{l}\text { Inhibits DHT-mediated AR } \\
\text { transactivation, inhibits transcription } \\
\text { of AR target genes (PSA, TMPRSS2, } \\
\text { and TMEPA1), Inhibits AR N/C- } \\
\text { Dimerization and formation of AR- } \\
\text { coregulatory complex, blocked E2 or } \\
\text { Adiol-mediated AR activity. }\end{array}$ & Xu, et al. [44] \\
\hline AR1-558 & $\begin{array}{l}\text { Decoys of AR NTD } \\
\text { residues } 1-558\end{array}$ & $\begin{array}{l}\text { Androgen } \\
\text { regulated genes }\end{array}$ & $\begin{array}{l}\text { Reduces the expression of androgen- } \\
\text { regulated genes HMGCR, KLK2, } \\
\text { KLK3/PSA, MAF, RHOU, and SAT1, } \\
\text { blocks AR-ARE interactions. }\end{array}$ & Myung, et al. [45] \\
\hline $\begin{array}{l}\text { Galeterone (ongoing } \\
\text { clinical trials) }\end{array}$ & $\begin{array}{l}3 \beta \text {-(hydroxy)-17-(1H- } \\
\text { benzimidazole-1-yl) } \\
\text { androstane-5,16-dione }\end{array}$ & $\begin{array}{l}\text { Androgen } \\
\text { receptor }\end{array}$ & $\begin{array}{l}\text { CYP17 inhibition, AR antagonist and } \\
\text { AR degrader. }\end{array}$ & $\begin{array}{l}\text { Bastos \& Antonarakis } \\
{[46]}\end{array}$ \\
\hline Compound $6 \mathrm{~m}$ & $\begin{array}{l}\text { 2-(4-phenylthiazol-2-yl) } \\
\text { isoindoline-1,3-dione } \\
\text { derivative }\end{array}$ & $\begin{array}{l}\text { Androgen } \\
\text { receptor }\end{array}$ & $\begin{array}{l}\text { Decreases androgen-mediated } \\
\text { transcription of ARE-mRNA in PSA, } \\
\text { TMPRSS2. }\end{array}$ & Saravanan, et al. [47] \\
\hline $\begin{array}{l}\text { NBBS } \\
\text { (N-butylbenzene } \\
\text { sulphonamide) }\end{array}$ & $\begin{array}{l}\text { Dichloromethane extract } \\
\text { from stem bark of } \\
\text { Pygeum africanum }\end{array}$ & $\begin{array}{l}\text { Androgen } \\
\text { hormone }\end{array}$ & $\begin{array}{l}\text { Inhibits AR mediated transactivation } \\
\text { and androgen hormone induction. }\end{array}$ & Schleich, et al. [48] \\
\hline $\begin{array}{l}\text { Isobavachin, } \\
\text { Glabranin, } \\
\text { Anthocyanin and } \\
\text { Eriosemation (via } \\
\text { structure based } \\
\text { docking studies) }\end{array}$ & Phytochemicals & $\begin{array}{l}\text { Androgen } \\
\text { receptor }\end{array}$ & AR antagonists. & Singh, et al. [49] \\
\hline Flutamide & Non-steroidal drug & $\begin{array}{l}\text { Androgen } \\
\text { receptor in } \\
\text { salivary duct } \\
\text { carcinoma }\end{array}$ & $\begin{array}{l}\text { Blocks DHT activity, inhibits invasion } \\
\text { of DHT mediated cells. }\end{array}$ & Kamata, et al. [50] \\
\hline $\begin{array}{l}\text { CID 70128824, CID } \\
70127147, \text { and CID } \\
70126881\end{array}$ & $\begin{array}{l}\text { 7a-substituted } \\
\text { dihydrotestosterones } \\
\text { by linear Quantitative } \\
\text { Structure-Activity } \\
\text { Relationship (QSAR) } \\
\text { model (in-silico } \\
\text { screening) }\end{array}$ & $\begin{array}{l}\text { Androgen } \\
\text { receptor } \\
\text { antagonists or } \\
\text { antiandrogens }\end{array}$ & & Wang, et al. [51] \\
\hline Metformin & $\begin{array}{l}\text { Anti-diabetic drug, } \\
\text { originally from Galega } \\
\text { officinalis (French lilac) }\end{array}$ & $\begin{array}{l}\text { Androgen } \\
\text { receptor }\end{array}$ & $\begin{array}{l}\text { Reduces mRNA and protein levels of } \\
\text { AR. }\end{array}$ & Whitburn, et al. [13] \\
\hline $\begin{array}{l}\text { Diterpenoids T1 and } \\
\text { its analogues T2 and } \\
\text { T3 }\end{array}$ & $\begin{array}{l}\text { Furanoditerpenoid } \\
\text { spongia-13(16), } \\
\text {-14-dien-19-oic acid }\end{array}$ & $\begin{array}{l}\text { Androgen } \\
\text { receptor }\end{array}$ & $\begin{array}{l}\text { Inhibits androgen-dependent } \\
\text { proliferation and AR transcriptional } \\
\text { activity, competes with androgen } \\
\text { binding to LBD of AR and blocks } \\
\text { essential N/C interactions. }\end{array}$ & Yang, et al. [15] \\
\hline $\begin{array}{l}\text { Combined Androgen } \\
\text { Blockade (CAB); } \\
\text { immediate switch } \\
\text { from Bicalutamide to } \\
\text { Flutamide }\end{array}$ & - & $\begin{array}{l}\text { Prostate Specific } \\
\text { Antigen (PSA) }\end{array}$ & Decreases the levels of PSA. & Yokomizo, et al. [52] \\
\hline $\begin{array}{l}\text { Acetyl-11-Keto- } \beta- \\
\text { Boswellic Acid } \\
\text { (AKBA) }\end{array}$ & $\begin{array}{l}\text { Acetyl-11-keto-b- } \\
\text { boswellic acid isolated } \\
\text { from the gum-resin of } \\
\text { Boswellia carterii }\end{array}$ & $\begin{array}{l}\text { Androgen } \\
\text { receptor in } \\
\text { prostate cancer }\end{array}$ & $\begin{array}{l}\text { Decrease DHT induced AR expression } \\
\text { at both mRNA and protein levels, } \\
\text { interruption of Sp1 binding activity, } \\
\text { suppression of androgen induction of } \\
\text { PSA promoter. }\end{array}$ & Yuan, et al. [53] \\
\hline $\begin{array}{l}\text { 6-Bromoindirubin-3- } \\
\text { Oxime } \\
(6 \mathrm{BIO})\end{array}$ & $\begin{array}{l}\text { 6-bromo-indirubin- } \\
30 \text {-oxime via small } \\
\text { molecule high } \\
\text { throughput screening }\end{array}$ & $\begin{array}{l}\text { Androgen } \\
\text { receptor and } \\
\text { its signaling in } \\
\text { prostate cancer }\end{array}$ & $\begin{array}{l}\text { Down-regulates AR-V7 levels, a } \\
\text { drug-resistance-related AR splice } \\
\text { variant, enhanced ASO (Antisense } \\
\text { oligonucleotides) function, represses } \\
\text { AR expression by inhibition of two main } \\
\text { Glycogen Synthase Kinase } 3 \text { (GSK-3) } \\
\text { isoforms, GSK-3a and GSK-3b. }\end{array}$ & Zhang, et al. [54] \\
\hline
\end{tabular}




\section{Conclusion}

Ever since the role of androgen and AR signaling has been elucidated in wide variety of cancers, extensive research has been dedicated towards the discovery of next generation drugs from a myriad source, that specifically antagonize the AR signaling cascade, stop metastasis and proliferation of respective cancers. Multiple factors including age, type of cancer, status of metastasis and intensity of side effects, have to be taken into consideration while developing new therapeutic drugs for cancers. This article summarizes new molecules and compounds that have been successfully used and proved to decrease the expression of antigenic biomarker (PSA) and AR in cancer cells. The roles of AR have been clearly elucidated in prostate and breast cancer subtypes. However, more research need to be conducted on other cancer subtypes such as bladder cancer, salivary cancer, oesophageal cancer and neuroblastomas, in which the roles of androgens and AR have not been studied extensively. Therefore, understanding precise molecular mechanisms underlying androgen mediated malignancies would shed light on developing prospective targeted therapies to combat cancer. Future research efforts have been directed towards disrupting AR signaling axis, likely with small molecule inhibitors or by rational combinations of other potential targeted therapies, in order to make continued advances in our understanding of AR signaling mechanisms in different cancer subtypes, which would increase our ability to effectively treat androgen associated malignancies.

\section{Conflicts of Interest}

Authors declare no conflict of interest.

\section{References}

1. Li P, Chen J, Miyamoto H (2017) Androgen Receptor Signaling in Bladder Cancer. Cancers (Basel) 9: 20.

2. Marcoccia D, Pellegrini M, Fiocchetti M, et al. (2017) Food components and contaminants as (anti) androgenic molecules. Genes Nutr 12: 6.

3. Lee MS, Lee SO, Kim SH, et al. (2016) Anti-Cancer Effect of Lambertianic Acid by Inhibiting the AR in LNCaP Cells. Int J Mol Sci 17: 1066.

4. Banuelos CA, Lal A, Tien AH, et al. (2014) Characterization of niphatenones that inhibit androgen receptor $\mathrm{N}$-terminal domain. PLoS One 9: e107991.

5. Davey RA, Grossmann M (2016) Androgen Receptor Structure, Function and Biology: From bench to bedside. Clin Biochem Rev 37: 3-15.

6. Banuelos CA, Tavakoli I, Tien AH, et al. (2016) Sintokamide $A$ Is a Novel Antagonist of Androgen Receptor That Uniquely Binds Activation Function-1 in Its Amino-Terminal Domain. J Biol Chem 291: 22231-22243.

7. Cui X, Cui M, Asada R, et al. (2016) The androgen-induced protein AlbZIP facilitates proliferation of prostate cancer cells through downregulation of p21 expression. Scientific Reports 6: 37310.
8. Kim SK, Seok H, Park HJ, et al. (2015) Inhibitory effect of curcumin on testosterone induced benign prostatic hyperplasia rat model. BMC Complement Altern Med 15: 380.

9. Eisermann K, Fraizer G (2017) The Androgen Receptor and VEGF: Mechanisms of Androgen-Regulated Angiogenesis in Prostate Cancer. Cancers 9.

10. Jiang C, Lee HJ, Li GX, et al. (2006) Potent antiandrogen and androgen receptor activities of an Angelica gigas-containing herbal formulation: identification of decursin as a novel and active compound with implications for prevention and treatment of prostate cancer. Cancer Res 66: 453-463.

11. Ceder Y, Bjartell A, Culig Z, et al. (2016) The Molecular Evolution of Castration-resistant Prostate Cancer. Eur Urol Focus 2: 506-513.

12. Tilki D, Schaeffer EM, Evans CP (2016) Understanding Mechanisms of Resistance in Metastatic Castration-resistant Prostate cancer: The Role of the Androgen Receptor. Eur Urol Focus 2: 499-505.

13. Whitburn J, Edwards CM, Sooriakumaran P (2017) Metformin and Prostate Cancer: a New Role for an Old Drug. Curr Urol Rep 18: 46.

14. Johnson JK, Skoda EM, Zhou J, et al. (2016) Small Molecule Antagonists of the Nuclear Androgen Receptor for the Treatment of Castration-Resistant Prostate Cancer. ACS Med Chem Lett 7: 785-790.

15. Yang YC, Meimetis LG, Tien AH, et al. (2013) Spongian diterpenoids inhibit androgen receptor activity. Mol Cancer Ther 12: 621-631.

16. Armandari I, Hamid AR, Verhaegh G (2014) Intratumoral steroidogenesis in castration-resistant prostate cancer: a target for therapy. Prostate Int 2: 105-113.

17. Chang TS, Lin HK, Rogers KA, et al. (2013) Expression of aldo-keto reductase family 1 member C3 (AKR1C3) in neuroendocrine tumors \& adenocarcinomas of pancreas, gastrointestinal tract, and lung. Int $\mathrm{J}$ Clin Exp Pathol 6: 2419-2429.

18. Penning TM, Byrns MC (2009) Steroid hormone transforming aldo-keto reductases and cancer. Ann N Y Acad Sci 1155: 33-42.

19. Rahim B, O'Regan R (2017) AR Signaling in Breast Cancer. Cancers 9.

20. Endogenous Hormones \& Breast Cancer Collaborative Group (2013) Sex hormones and breast cancer risk in premenopausal women: Collaborative reanalysis of seven prospective studies. Lancet Oncol 14: 1009-1019.

21. Gordon MA, D'Amato NC, Gu H, et al. (2017) Synergy between Androgen Receptor Antagonism and Inhibition of mTOR and HER2 in Breast Cancer. Mol Cancer Ther 16: 1389-1400.

22. Wu Y, Vadgama JV (2017) Androgen Receptor as a Potential Target for Treatment of Breast Cancer. Int J Cancer Res Mol Mech 3.

23. López-Marure R, Zapata-Gómez E, Rocha-Zavaleta L, et al. (2016) Dehydroepiandrosterone inhibits events related with the metastatic process in breast tumor cell lines. Cancer Biol Ther 17: 915-924.

24. Sukocheva OA, Li B, Due SL, et al. (2015) Androgens and esophageal cancer: What do we know? World J Gastroen- 
Citation: Bandyopadhyay M, Muthuirulan P (2017) Androgen Signaling: Promising Target for Prospective Cancer Therapy. J Drug Des Devel 1(1):1-10

terol 21: 6146-6156.

25. Sun J, Wang D, Guo L, et al. (2017) Androgen Receptor Regulates the Growth of Neuroblastoma Cells in vitro and in vivo. Front Neurosci 11: 116.

26. Dalin MG, Watson PA, Ho AL, et al. (2017) Androgen Receptor Signaling in Salivary Gland Cancer. Cancers 9: 17.

27. O'Neill D, Jones D, Wade M, et al. (2015) Development and exploitation of a novel mutant androgen receptor modelling strategy to identify new targets for advanced prostate cancer therapy. Oncotarget 6: 26029-26040.

28. Proverbs-Singh T, Feldman JL, Morris MJ, et al. (2015) Targeting the androgen receptor in prostate and breast cancer: several new agents in development. Endocr Relat Cancer 22: 87-106.

29. Lepor H, Shore ND (2012) LHRH Agonists for the Treatment of Prostate Cancer: 2012. Rev Urol 14: 1-12.

30. Secky L, Svoboda M, Klameth L, et al. (2013) The Sulfatase Pathway for Estrogen Formation: Targets for the Treatment and Diagnosis of Hormone-Associated Tumors. Journal of Drug Delivery 2013: 957605.

31. Cho CH, Bae JS, Kim YU (2010) 5alpha-reductase inhibitory components as antiandrogens from herbal medicine. $\mathrm{J}$ Acupunct Meridian Stud 3: 116-118.

32. Hoang DT, Iczkowski KA, Kilari D, et al. (2017) Androgen receptor-dependent and-independent mechanisms driving prostate cancer progression: Opportunities for therapeutic targeting from multiple angles. Oncotarget 8: 3724-3745.

33. Choi HE, Shin JS, Leem DG, et al. (2016) 6-(3,4-Dihydro-1H-isoquinoline-2-yl)-N-(6-methoxypyridine-2-yl) nicotinamide-26 (DIMN-26) decreases cell proliferation by induction of apoptosis and downregulation of androgen receptor signaling in human prostate cancer cells. Chem Biol Interact 260: 196-207.

34. Zhang L, Zhao Z, Xu S, et al. (2017) Androgen suppresses protein kinase D1 expression through fibroblast growth factor receptor substrate 2 in prostate cancer cells. Oncotarget 8: 12800-12811.

35. Rosati R, Patki M, Chari V, et al. (2016) The Amino-terminal Domain of the Androgen Receptor Co-opts Extracellular Signal-regulated Kinase (ERK) Docking Sites in ELK1 Protein to Induce Sustained Gene Activation That Supports Prostate Cancer Cell Growth. J Biol Chem 291: 25983-25998.

36. Deep G, Gangar SC, Oberlies NH, et al. (2010) Isosilybin A induces apoptosis in human prostate cancer cells via targeting Akt, NF-kB, and androgen receptor signaling. Mol Carcinog 49: 902-912.

37. Otto-Duessel M, Tew BY, Vonderfecht S, et al. (2017) Identification of neuron selective androgen receptor inhibitors. World J Biol Chem 8: 138-150.

38. Fajardo AM, MacKenzie DA, Olguin SL, et al. (2016) Antioxidants Abrogate Alpha-Tocopherylquinone-Mediated Down-Regulation of the Androgen Receptor in Androgen-Responsive Prostate Cancer Cells. PLoS One 11: e0151525.

39. Ferroni C, Pepe A, Kim YS, et al. (2017) 1,4-Substituted Triazoles as Nonsteroidal Anti-Androgens for Prostate Cancer Treatment. J Med Chem 60: 3082-3093.
40. Fizazi K, Massard C, James ND, et al. (2013) ODM-201, a new generation androgen receptor inhibitor for castration-resistant prostate cancer: Preclinical and phase I data. Journal of Clinical Oncology 31: 65.

41. Huang EC, Chen G, Baek SJ, et al. (2011) Zyflamend reduces the expression of androgen receptor in a model of castrate-resistant prostate cancer. Nutr Cancer 63: 12871296.

42. Ingersoll MA, Lyons AS, Muniyan S, et al. (2015) Novel Imidazopyridine Derivatives Possess Anti-Tumor Effect on Human Castration-Resistant Prostate Cancer Cells. PLoS One 10: e0131811.

43. Isharwal S, Modi S, Arora N, et al. (2017) Minnelide Inhibits Androgen Dependent, Castration Resistant Prostate Cancer Growth by Decreasing Expression of Androgen Receptor Full Length and Splice Variants. Prostate 77: 584-596.

44. Xu D, Lin TH, Li S, et al. (2012) Cryptotanshinone suppresses androgen receptor-mediated growth in androgen dependent and castration resistant prostate cancer cells. Cancer Lett 316: 11-22.

45. Myung JK, Wang G, Chiu HH, et al. (2017) Inhibition of androgen receptor by decoy molecules delays progression to castration-recurrent prostate cancer. PLoS One 12: e0174134.

46. Bastos DA, Antonarakis ES (2016) Galeterone for the treatment of advanced prostate cancer: the evidence to date. Drug Des Devel Ther 10: 2289-2297.

47. Saravanan K, Elancheran R, Divakar S, et al. (2017) Design, synthesis and biological evaluation of 2-(4-phenylthiazol-2-yl) isoindoline-1,3-dione derivatives as anti-prostate cancer agents. Bioorg Med Chem Lett 27: 1199-1204.

48. Schleich S, Papaioannou M, Baniahmad A, et al. (2006) Extracts from Pygeum africanum and other ethnobotanical species with antiandrogenic activity. Planta Med 72: 807-813.

49. Singh AN, Baruah MM, Sharma N (2017) Structure Based docking studies towards exploring potential anti-androgen activity of selected phytochemicals against Prostate Cancer. Sci Rep 7: 1955.

50. Kamata YU, Sumida T, Murase R, et al. (2016) Blockade of Androgen-induced Malignant Phenotypes by Flutamide Administration in Human Salivary Duct Carcinoma Cells. Anticancer Res 36: 6071-6075.

51. Wang $\mathrm{Y}$, Han R, Zhang H, et al. (2017) Combined Ligand/ Structure-Based Virtual Screening and Molecular Dynamics Simulations of Steroidal Androgen Receptor Antagonists. BioMed Research International 2017: 3572394.

52. Yokomizo Y, Kawahara T, Miyoshi Y, et al. (2016) Efficacy of Immediate Switching from Bicalutamide to Flutamide as Second-Line Combined Androgen Blockade. Biomed Res Int 2016: 4083183.

53. Yuan $\mathrm{HQ}$, Kong $\mathrm{F}$, Wang $\mathrm{XL}$, et al. (2008) Inhibitory effect of acetyl-11-keto-beta-boswellic acid on androgen receptor by interference of Sp1 binding activity in prostate cancer cells. Biochem Pharmacol 75: 2112-2121.

54. Zhang X, Castanotto D, Nam S, et al. (2017) 6BIO Enhances Oligonucleotide Activity in Cells: A Potential Combinatorial Anti-Androgen Receptor Therapy in Prostate Cancer Cells. Mol Ther 25: 79-91. 